\title{
RADIOCARBON IN THE WATER COLUMN OF THE SOUTHWESTERN NORTH PACIFIC OCEAN-24 YEARS AFTER GEOSECS
}

\author{
Pavel P Povinec ${ }^{1,2} \bullet$ Takafumi Aramaki ${ }^{3}$ George S Burr ${ }^{4} \bullet$ A J Timothy Jull ${ }^{4} \bullet$ \\ Laval Liong Wee Kwong ${ }^{1} \cdot$ Orihiko Togawa ${ }^{1,3}$
}

\begin{abstract}
In the framework of the Worldwide Marine Radioactivity Studies (WOMARS) project, water profile samples for radiocarbon measurements were taken during the IAEA'97 cruise at 10 stations in the southwestern North Pacific Ocean. While ${ }^{14} \mathrm{C}$ concentrations were rapidly decreasing from the surface $\left(\Delta^{14} \mathrm{C}\right.$ about $\left.100 \%\right)$ down to about $800 \mathrm{~m}$ at all visited stations $\left(\Delta^{14} \mathrm{C}\right.$ about $-200 \%$ ), the concentrations below $1000 \mathrm{~m}$ were almost constant. Some stations were in proximity to the GEOSECS stations sampled in 1973 ; thus, ${ }^{14} \mathrm{C}$ profiles could be compared after a 24 -yr interval. Generally, ${ }^{14} \mathrm{C}$ concentrations had decreased in surface waters (by 50-80\%) and increased (by about the same amount) in intermediate waters when compared with GEOSECS data. In deep waters (below $1000 \mathrm{~m}$ ), the observed ${ }^{14} \mathrm{C}$ concentrations were similar to GEOSECS values. The bomb-produced ${ }^{14} \mathrm{C}$ inventory had increased by more than $20 \%$ over the 24 yr from 1973 to 1997 and was estimated to be about $(32 \pm 5) 10^{12}$ atom m${ }^{-2}$, with an annual ${ }^{14} \mathrm{C}$ flux of $(1.3 \pm 0.3) 10^{12}$ atom m${ }^{-2} \mathrm{yr}^{-1}$. The results suggest that bomb-produced ${ }^{14} \mathrm{C}$ has been advected northwards by the Kuroshio Current and the Kuroshio Extension and stored in the intermediate layer as North Pacific Intermediate Water.
\end{abstract}

\section{INTRODUCTION}

From 1995 to 2002, the International Atomic Energy Agency's Marine Environment Laboratory (IAEA-MEL), Monaco, in collaboration with 35 institutes, carried out a research project entitled Worldwide Marine Radioactivity Studies (WOMARS). The main objectives were the following:

- To identify the major sources of anthropogenic radionuclides in the world's oceans and seas;

- To develop present knowledge of concentrations and distributions of the key radionuclides${ }^{3} \mathrm{H},{ }^{14} \mathrm{C},{ }^{90} \mathrm{Sr},{ }^{129} \mathrm{I},{ }^{137} \mathrm{Cs}$, and $\mathrm{Pu}$ isotopes - in water and sediment of the world's oceans and seas;

- To study the changes in radionuclide concentrations in the oceans with time using good quality historical data (e.g. from the Geochemical Ocean Sections Programme [GEOSECS] of the mid1970s) and new data sets collected recently.

In the framework of the WOMARS project, in November 1997, IAEA-MEL organized a research cruise (IAEA'97 Pacific Ocean Expedition) to sample seawater, sediment, and biota in the southwestern North Pacific Ocean. The objectives of this expedition were to develop an understanding of the present open ocean distribution of radionuclides for comparison with data sets obtained in an earlier (GEOSECS) and a more recent (World Ocean Circulation Experiment [WOCE]) international survey of radionuclides in the same region and, specifically, to trace global fallout radionuclides and radionuclides produced during nuclear weapons tests (local fallout) carried out at the Marshall Islands (Povinec and Togawa 1999; Povinec et al. 2003).

\section{Background Oceanography}

Specific circulation patterns in the southwestern North Pacific Ocean make radionuclide tracers particularly useful. In the equatorial region, the North Equatorial Current (NEC) is the dominant surface current which flows westward at the southern boundary of the survey area (around Pohnpei),

\footnotetext{
${ }^{1}$ International Atomic Energy Agency, Marine Environment Laboratory, Monte-Carlo, MC 98012 Monaco.

${ }^{2}$ Corresponding author. Email: p.povinec@iaea.org.

${ }^{3}$ Japan Atomic Energy Research Institute, Marine Research Laboratory, Mutsu, Aomori-ken, Japan.

${ }^{4}$ University of Arizona, NSF Arizona AMS Facility, Tucson, Arizona, USA.
} 
and on reaching the island of Honshu, merges into the Kuroshio Current. The Kuroshio Current leaves the Japanese coast at between $36^{\circ} \mathrm{N}$ and $39^{\circ} \mathrm{N}$ and meets the Oyashio Current (subarctic gyre). The Kuroshio Extension bifurcates at around $155^{\circ} \mathrm{E}$ into the main current and a northern branch (Kawabe and Taira 1998).

The dominant water masses in the North Pacific are the North Pacific Tropical Waters (NPTW), the North Pacific SubTropical Mode Waters (NPSTMW), and the North Pacific Intermediate Waters (NPIW). NPTW are composed of saline surface water produced in the central region of the North Pacific, while NPSTMW and NPIW are generated in the western North Pacific. NPSTMW are defined as a voluminous water mass in an isothermal layer around $16.5^{\circ} \mathrm{C}$ and a layer of potential vorticity minimum $<2 \times 10^{-12} \mathrm{~cm}^{-1} \mathrm{~s}^{-1}$, which is formed by deep vertical convection in winter just south of the Kuroshio Current and the Kuroshio Extension (Suga et al. 1989). NPIW exist in the intermediate minimum salinity layer at isopycnal $26.8 \sigma_{\theta}$ (potential density) and at isopycnal $27.28 \sigma_{\theta}$, respectively (Reid 1965). NPIW are formed in the region where subtropical waters mix with subarctic waters and then extend to the subtropical gyre (Talley 1993). The deep waters in the investigated area are composed of North Pacific Deep Waters (NPDW).

\section{${ }^{14} \mathrm{C}$ in the Water Column of the Southwestern North Pacific}

Radiocarbon enters the ocean through air-sea $\mathrm{CO}_{2}$ gas exchange, with an equilibration time of 7 to $10 \mathrm{yr}$. It mainly exists as dissolved inorganic carbonic acid in seawater. Due to its radioactive decay, dissolved inorganic ${ }^{14} \mathrm{C}\left(\mathrm{DI}^{14} \mathrm{C}\right)$ in the ocean decreases from the time it enters the ocean, allowing $\mathrm{DI}^{14} \mathrm{C} /{ }^{12} \mathrm{C}$ ratios in seawater to be used to calculate the "age" of seawater (Tsunogai 1981). In the $1950 \mathrm{~s}$ and 1960s, atmospheric testing of nuclear weapons released large amounts of ${ }^{14} \mathrm{C}$ into the atmosphere, approximately doubling the pre-bomb levels (Levin et al. 1985). Subsequently, surface water in the ocean containing ${ }^{14} \mathrm{C}$ originating from these tests gradually spread deeper into the ocean. Thus, the ${ }^{14} \mathrm{C}$ of bomb origin has provided a means to study air-sea gas exchange and trace intermediate and deep water circulation in the oceans over the last few decades (e.g. Broecker et al. 1985). Broecker et al. (1995) found a relationship between ${ }^{14} \mathrm{C}$ concentration and silicate contents in deep water where no effects of bomb tests were observed, and proposed a method for separation of natural and bomb components of observed vertical $\Delta^{14} \mathrm{C}$ profiles. Their method is widely used for estimating the bomb- ${ }^{14} \mathrm{C}$ inventory in the ocean (Peng et al. 1998; Leboucher et al. 1999; Watanabe et al. 1999).

In this paper, we present and discuss ${ }^{14} \mathrm{C}$ data obtained for the water column of the southwestern North Pacific Ocean sampled during the IAEA'97 Pacific Ocean Expedition. Some of the northern stations were located close to GEOSECS stations, and preliminary results have been published by Aramaki et al. (2001). In the current paper, we present the complete results and discuss the behavior of bomb ${ }^{14} \mathrm{C}$ in the southwestern North Pacific, including the bomb-produced ${ }^{14} \mathrm{C}$ inventory, over the 24-yr interval between 1973 and 1997.

\section{METHODS}

\section{Sampling}

In 1997 (21 October-20 November), seawater profile samples for ${ }^{14} \mathrm{C}$ measurements were collected at 10 stations in the southwestern North Pacific during the "IAEA'97 Pacific Ocean Expedition" on board the research vessel "Bosei Maru" (Tokai University, Japan) (Figure 1). Four IAEA stations (IAEA-2, 2B, 3, and 4) were close to GEOSECS stations (GEOSECS-223, 225, 226, and 227) sampled in 1973. IAEA Station 1 was located between GEOSECS Stations 224 and 223. IAEA Stations 
6 and 7 were located close to the Bikini and Enewetak Atolls, respectively. IAEA Stations 5, 8, and 9 , located north of the Marshall Islands, were chosen in order to trace radionuclides released as local fallout from the nuclear weapons tests.

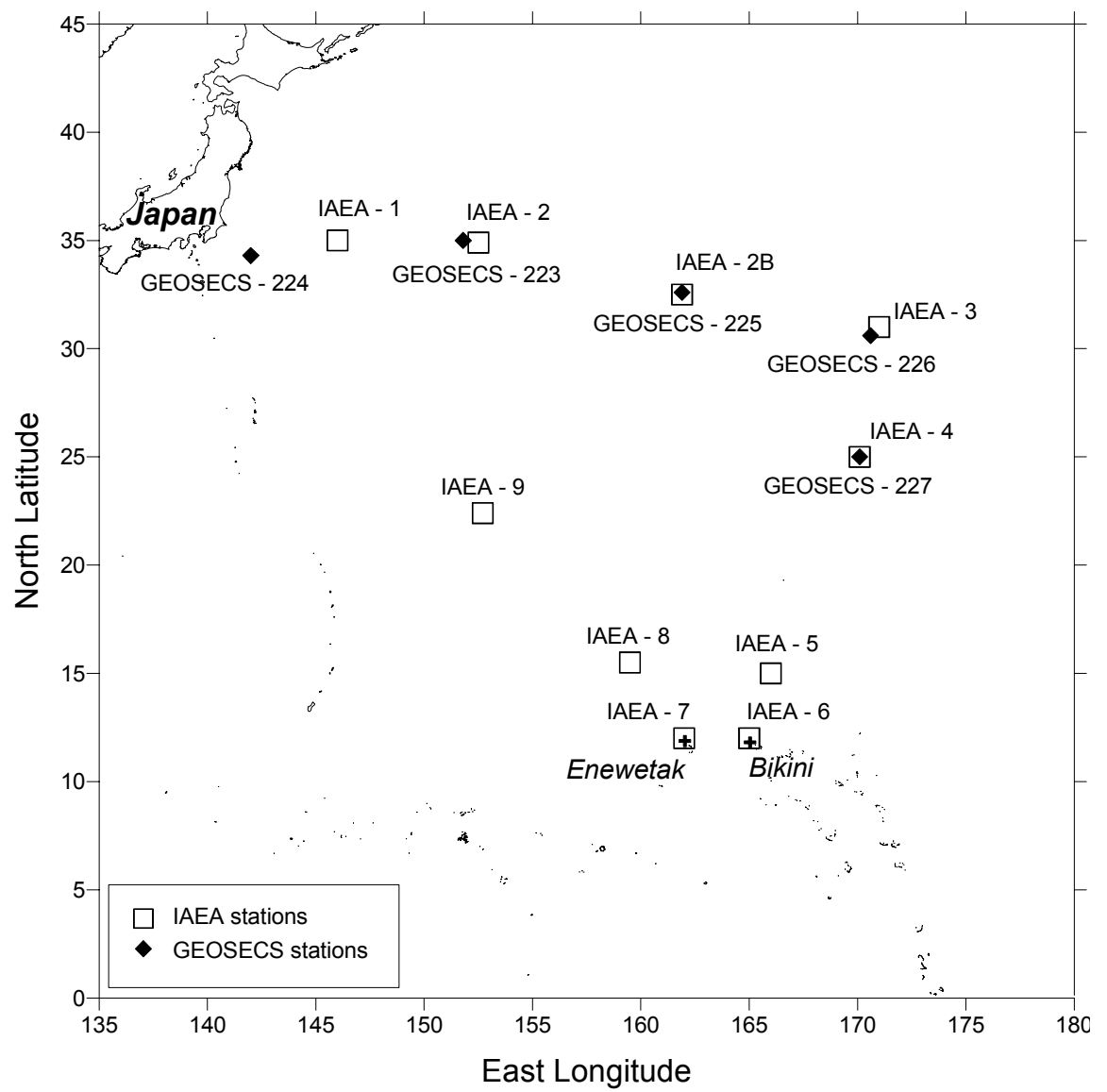

Figure 1 Sampling stations for ${ }^{14} \mathrm{C}$ measurements of the IAEA'97 Pacific Ocean Expedition and GEOSECS stations (1973)

Seawater samples for ${ }^{14} \mathrm{C}$ measurements were collected at each station using a CTD/RMS system equipped with Niskin bottles. Collected samples were stored in $500-\mathrm{mL}$ glass bottles with hermetic stoppers mixed with $100 \mu \mathrm{L}$ of saturated $\mathrm{HgCl}_{2}$ solution to poison the sample.

\section{Sample Preparation and ${ }^{14} \mathrm{C}$ Measurements}

${ }^{14} \mathrm{C}$ measurements of samples taken at 6 stations $(1,2 \mathrm{~B}, 4,5,8$, and 9$)$ were carried out at the Japan Atomic Energy Research Institute's Marine Research Laboratory in Mutsu, Japan (JAERI-MRL), and measurements of samples from the other 4 stations $(2,3,6$, and 7) were carried out at the University of Arizona's Accelerator Mass Spectrometry (AMS) facility in Tucson, Arizona. The seawater samples were prepared for the measurement of the ${ }^{14} \mathrm{C} /{ }^{12} \mathrm{C}$ or ${ }^{14} \mathrm{C} /{ }^{13} \mathrm{C}$ ratios in dissolved inorganic carbon (DIC) by both JAERI-MRL and the University of Arizona, using each laboratory's specific methods.

In the JAERI-MRL measurements, the DIC in the sample was extracted as $\mathrm{CO}_{2}$ gas by adding $4 \mathrm{~mL}$ of $100 \% \mathrm{H}_{3} \mathrm{PO}_{4}$, stripped using pure $\mathrm{N}_{2}$ gas, and cryogenically collected in a vacuum (Aramaki et 
al. 2000). The $\mathrm{CO}_{2}$ gas was reduced to graphite with pure $\mathrm{H}_{2}$ gas over an $\mathrm{Fe}$ catalyst at $650{ }^{\circ} \mathrm{C}$ (Kitagawa et al. 1993; Aramaki et al. 2000). Graphite was pressed into targets for AMS ${ }^{14} \mathrm{C}$ measurements. The stable isotopic composition of sub-samples of the $\mathrm{CO}_{2}$ gas was measured in a Finnigan

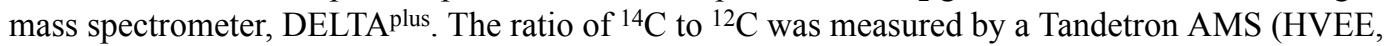
model 4130-AMS) at JAERI-MRL. The ${ }^{14} \mathrm{C}$ activity in seawater samples has been expressed as $\Delta^{14} \mathrm{C}$ (Stuiver 1980; Aramaki et al. 2001).

In the University of Arizona measurements, the DIC in seawater was extracted by acidification of the sample to $\mathrm{pH} 3$ and the $\mathrm{CO}_{2}$ released was cryogenically extracted in a flow of high-purity $\mathrm{O}_{2}$ gas. The $\mathrm{CO}_{2}$ gas was reduced to graphite over an Fe catalyst, following the procedure described by Donahue et al. (1990a). Graphite was pressed into targets for AMS ${ }^{14} \mathrm{C}$ measurements. The stable isotopic composition of sub-samples of $\mathrm{CO}_{2}$ gas was measured in an Optima mass spectrometer. The ratio of ${ }^{14} \mathrm{C}$ to ${ }^{13} \mathrm{C}$ was measured at the NSF Accelerator Facility for Radioisotope Analysis at the University of Arizona. The ${ }^{14} \mathrm{C}$ activity in seawater samples is expressed by the $\Delta{ }^{14} \mathrm{C}$ value (Stuiver 1980; Donahue et al. 1990b).

Intercomparison measurements were carried out on seawater samples collected at Station 1 which showed good agreement between both laboratories (Liong et al., these proceedings).

\section{RESULTS AND DISCUSSION}

\section{${ }^{14} \mathrm{C}$ Vertical Profiles}

${ }^{14} \mathrm{C}$ vertical profile measurements are presented in Figure 2 and Table 1 (only data from the University of Arizona [Stations 2, 4, 6, and 7] are given in the table, as the JAERI-MRI data were published by Aramaki et al. 2001). All profiles have similar curves, although differences can be observed at surface and sub-surface water depths. Generally, the $\Delta^{14} \mathrm{C}$ values below $1000 \mathrm{~m}$ are the same within uncertainties, except for Station 7 which shows the lowest observed $\Delta^{14} \mathrm{C}$ values (at the surface and 1000-2500 m water depths) in contrast to the other radionuclides measured (Povinec et al. 2003). We do not understand at present the reason for this offset, since there are not available comparable data from GEOSECS and WOCE. Surface concentrations (in top $150 \mathrm{~m}$ ) differ for different stations, and as shown in Figure 3, there is still a visible latitudinal effect, although it probably differs from the original global fallout input. A similar trend was observed for other radionuclides as well (Povinec et al. 2003).

\section{Comparison with WOCE and GEOSECS Data}

A very comprehensive $\Delta^{14} \mathrm{C}$ data set for the Pacific Ocean has been published recently by the WOCE collaboration (Key et al. 2002). Although the WOCE stations in the southwestern Pacific (sampled in 1993) differ from the WOMARS stations, a comparison presented in Figure 4 for stations in similar latitudinal belts (IAEA Stations 1, 2B, and 3 versus WOCE Stations 78 and 80) shows that WOMARS data are comparable to WOCE data.

A comparison of our $\Delta^{14} \mathrm{C}$ profiles with GEOSECS results (Ostlund and Stuiver 1980) are presented in Figure 5 (only stations situated in the northwest Pacific could be compared, as there are no GEOSECS data for stations in the southwest). At Stations $2 \mathrm{~B}, 3$, and 4 , our $\Delta{ }^{14} \mathrm{C}$ values in the surface layer $(<200 \mathrm{~m}$ ) are lower than the GEOSECS values (by up to $50-80 \%$ ) but higher (by up to about $60 \%$ ) in the sub-surface layer $(200-800 \mathrm{~m})$. As other recent ${ }^{14} \mathrm{C}$ measurements in the subtropical western North Pacific also indicate an increase of $\Delta{ }^{14} \mathrm{C}$ values in intermediate waters (Gamo et al. 1987; Watanabe et al. 1999; Aramaki 2002; Key et al. 2002), our results are consistent with their observations. 

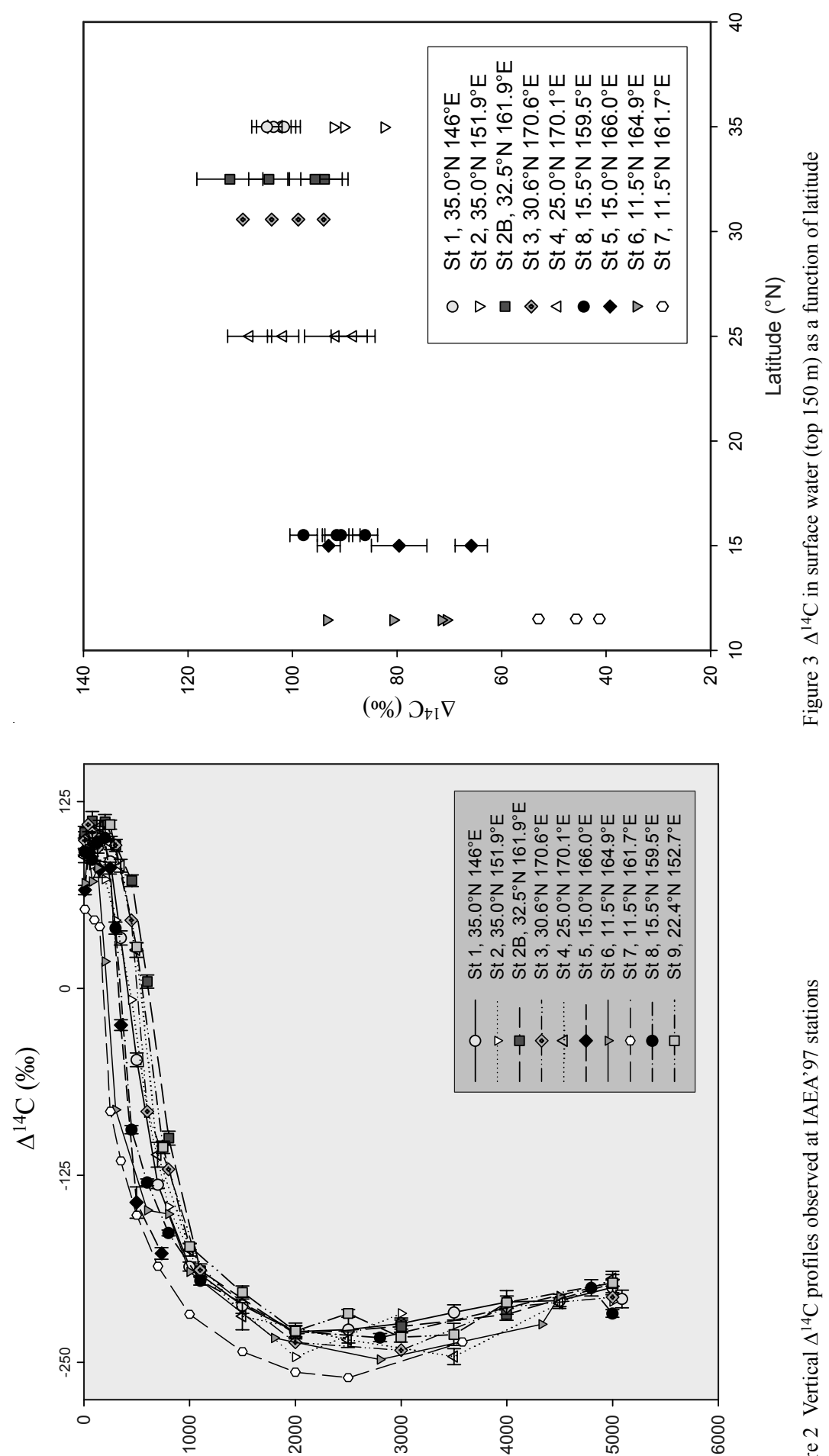

(u) чฺdәव 
Table $1 \Delta^{14} \mathrm{C}$ data for IAEA'97 Stations 2, 3, 6, and 7 .

\begin{tabular}{|c|c|c|c|c|c|}
\hline Location & $\begin{array}{l}\text { Depth } \\
\text { (m) }\end{array}$ & $\begin{array}{l}\Delta^{14} \mathrm{C} \\
(\% 0)\end{array}$ & Location & $\begin{array}{l}\text { Depth } \\
\text { (m) }\end{array}$ & $\begin{array}{l}\Delta^{14} \mathrm{C} \\
(\%)\end{array}$ \\
\hline Station 2 & & & Station 6 & & \\
\hline \multirow{14}{*}{$34.97^{\circ} \mathrm{N}, 151.89^{\circ} \mathrm{E}$} & 10 & $92.2 \pm 5.1$ & \multirow[t]{14}{*}{$11.45^{\circ} \mathrm{N}, 164.88^{\circ} \mathrm{E}$} & 10 & $70.5 \pm 4.1$ \\
\hline & 40 & $90.2 \pm 5.0$ & & 40 & $93.4 \pm 5.2$ \\
\hline & 80 & $82.5 \pm 4.2$ & & 80 & $71.5 \pm 4.2$ \\
\hline & 130 & - & & 130 & $80.7 \pm 4.6$ \\
\hline & 200 & $73.0 \pm 4.1$ & & 200 & $18.1 \pm 2.9$ \\
\hline & 300 & $45.7 \pm 2.9$ & & 300 & $-81.1 \pm-4.4$ \\
\hline & 450 & $-7.6 \pm-3.0$ & & 450 & - \\
\hline & 600 & $-83.3 \pm-4.3$ & & 600 & $-148.3 \pm-7.5$ \\
\hline & 800 & $-145.9 \pm-7.5$ & & 800 & $-150.8 \pm-8.0$ \\
\hline & 1100 & $-191.2 \pm-10.0$ & & 1000 & $-189.6 \pm-9.7$ \\
\hline & 2000 & $-246.5 \pm-12.0$ & & 1800 & $-233.7 \pm-12.1$ \\
\hline & 3000 & $-217.3 \pm-11.0$ & & 2800 & $-248.2 \pm-1.2$ \\
\hline & 4000 & - & & 4330 & $-224.5 \pm-11.5$ \\
\hline & 5000 & $-209.4 \pm-10.6$ & & 4500 & $-205.9 \pm-10.7$ \\
\hline Station 3 & & & Station 7 & & \\
\hline \multirow[t]{14}{*}{$30.57^{\circ} \mathrm{N}, 170.62^{\circ} \mathrm{E}$} & 10 & $98.9 \pm 5.5$ & \multirow[t]{14}{*}{$11.5^{\circ} \mathrm{N}, 161.74^{\circ} \mathrm{E}$} & 10 & $53.0 \pm 3.4$ \\
\hline & 40 & $109.5 \pm 5.8$ & & 100 & $45.7 \pm 2.9$ \\
\hline & 80 & $104.0 \pm 5.7$ & & 150 & $41.3 \pm 2.9$ \\
\hline & 130 & $94.0 \pm 5.3$ & & 250 & $-82.2 \pm-4.8$ \\
\hline & 200 & - & & 350 & $-115.3 \pm-6.6$ \\
\hline & 300 & $95.8 \pm 5.3$ & & 500 & $-151.7 \pm-8.1$ \\
\hline & 450 & $45.6 \pm 2.8$ & & 700 & $-185.8 \pm-9.6$ \\
\hline & 600 & $-82.2 \pm-4.3$ & & 1000 & $-217.9 \pm-11.1$ \\
\hline & 800 & $-121.0 \pm-6.4$ & & 1500 & $-242.9 \pm-12.1$ \\
\hline & 1100 & $-188.3 \pm-9.8$ & & 2000 & $-256.6 \pm-13.0$ \\
\hline & 2000 & $-236.7 \pm-12.0$ & & 2500 & $-260.3 \pm-13.0$ \\
\hline & 3000 & $-241.9 \pm-12.1$ & & 3580 & $-236.5 \pm-1.2$ \\
\hline & 4000 & $-213.1 \pm-11.3$ & & - & - \\
\hline & 5000 & $-206.5 \pm-10.5$ & & - & - \\
\hline
\end{tabular}

On the other hand, at Stations 1 and 2 , the $\Delta^{14} \mathrm{C}$ values are lower (by up to 50\%) in the layer above $1500 \mathrm{~m}$. At these stations, the differences between our and GEOSECS observations are found in vertical salinity profiles as well, and this may be caused by the influence of the saline Kuroshio Extension waters in the sampling region (Aramaki et al. 2001). Furthermore, Station 1 lies about $500 \mathrm{~km}$ to the east of GEOSECS Station 224 (see Figure 1). Thus, the differences in $\Delta^{14} \mathrm{C}$ vertical profiles at these stations are due to the presence of different water masses at the time of the 2 sampling missions, and it is difficult to directly compare data from Stations 1 and 2 with data from GEOSECS Stations 224 and 223, respectively. In Figure $6, \Delta{ }^{14} \mathrm{C}$ values at Stations 1 and 2 are plotted against density $\left(\sigma_{\theta}\right)$, and compared with GEOSECS Stations 224 and 223 , respectively. Our $\Delta^{14} \mathrm{C}$ values above $25.5 \sigma_{\theta}(250 \mathrm{~m}$ at Station 1 and $170 \mathrm{~m}$ at Station 2$)$ are lower than the GEOSECS values, but higher in the intermediate water layer with 25.5-27.0 $\sigma_{\theta}\left(27.0 \sigma_{\theta}=680 \mathrm{~m}\right.$ at Station 1 and $27.0 \sigma_{\theta}=700 \mathrm{~m}$ at Station 2). Stations 2B, 3, and 4 show a similar tendency, confirming that at least at Station 2, water masses have changed since the GEOSECS mission. 


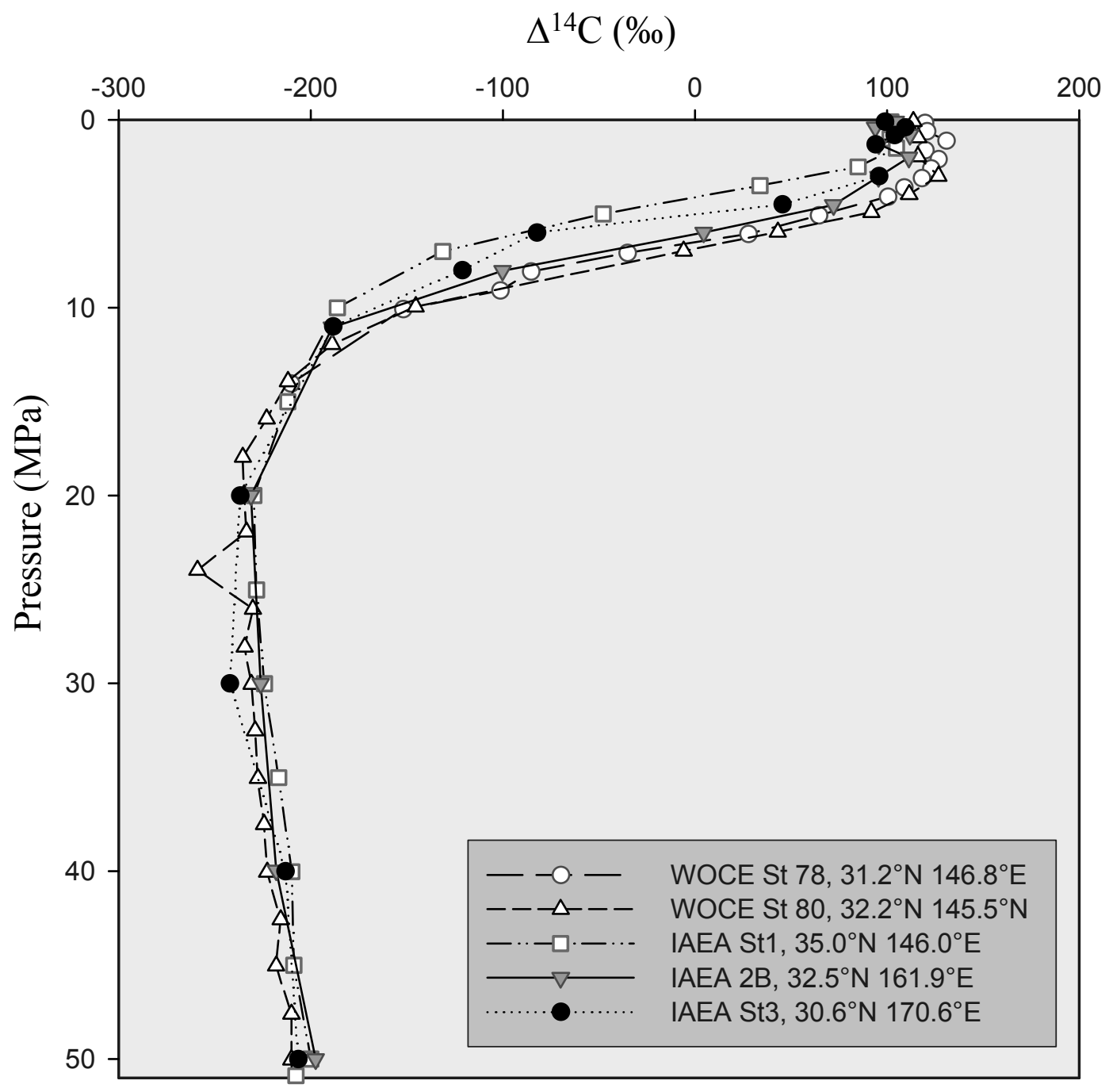

Figure 4 Comparison of vertical $\Delta^{14} \mathrm{C}$ profiles observed at IAEA'97 and WOCE (1993) stations 

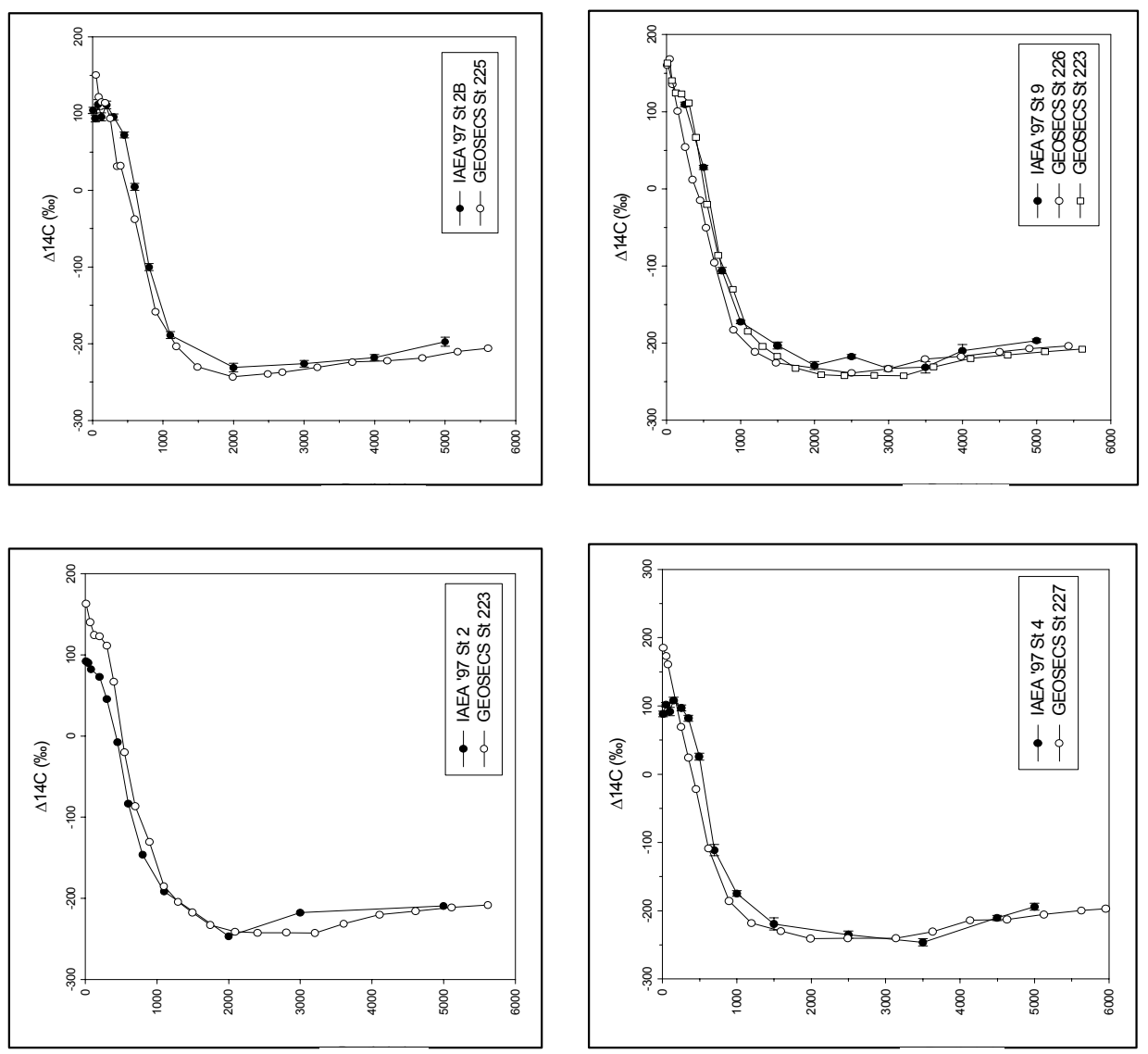

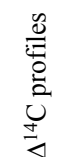

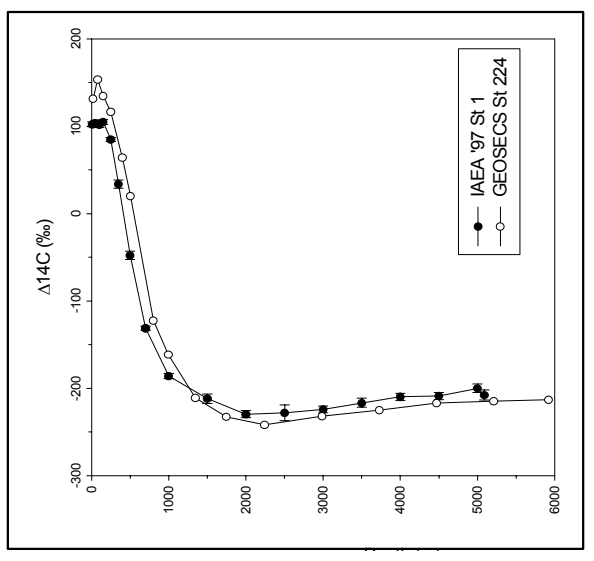

(ய) чұdəવ

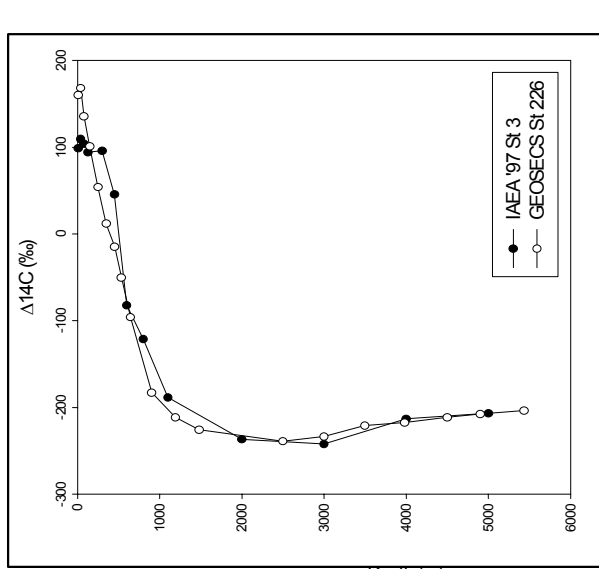

(u) чาdəव

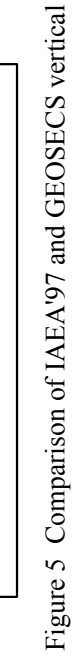



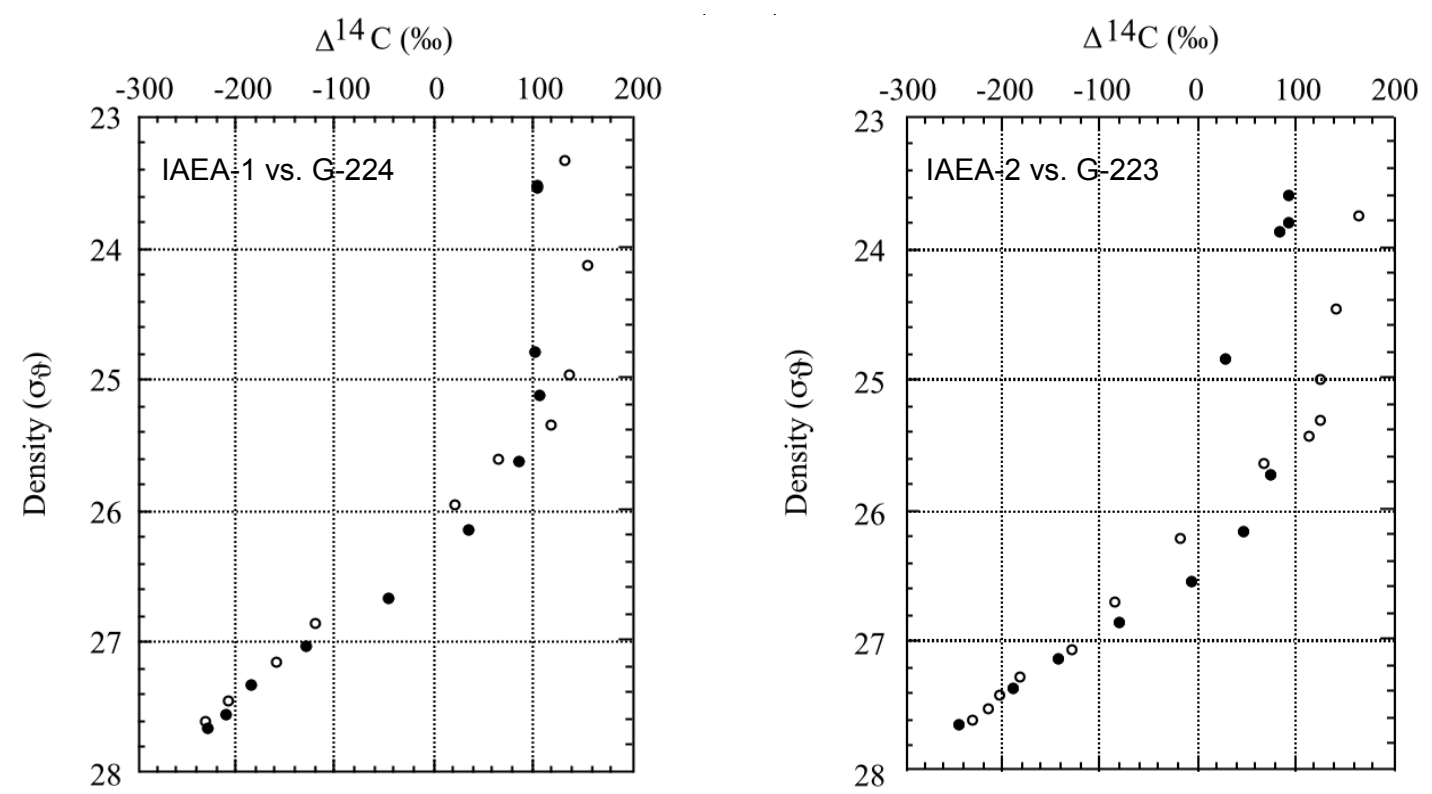

Figure 6 Comparison of $\Delta^{14} \mathrm{C}$ vertical profiles against density $\left(\sigma_{\theta}\right)$ between IAEA (dots) and GEOSECS (open circles) stations.

\section{Bomb ${ }^{14} \mathrm{C}$ Behavior in the Southwestern North Pacific}

Two sets of vertical profiles (this work and GEOSECS) are used to analyze the behavior of bomb ${ }^{14} \mathrm{C}$ in the southwestern North Pacific over the 24-yr period between 1973 and 1997 . The bomb ${ }^{14} \mathrm{C}$ content $\left({ }^{14} \mathrm{C}_{\text {bomb }}\right)$ is expressed as

$$
{ }^{14} C_{\text {bomb }}=\left(\Delta^{14} C_{o b s}-\Delta^{14} C_{\text {nat }}\right) \times \alpha \times \Sigma C O_{2}
$$

where $\alpha=1.176 \times 10^{-12}$ is the ratio of ${ }^{14} \mathrm{C} /{ }^{12} \mathrm{C}$ at $\Delta{ }^{14} \mathrm{C}=0 \%$, and $\Sigma \mathrm{CO}_{2}$ is the total carbonate content in mole $\mathrm{kg}^{-1}$, at the time of "observation" and "natural." Both $\Sigma \mathrm{CO}_{2}$ at the same depth are regarded as approximately similar values. Therefore, we can calculate the bomb ${ }^{14} \mathrm{C}$ inventory $\left(\mathrm{I}_{\mathrm{bomb}}\right)$, integrating ${ }^{14} \mathrm{C}_{\text {bomb }}$ from the surface to the lower limit of the bomb ${ }^{14} \mathrm{C}$ penetration depth $(\mathrm{z}, \mathrm{m})$ by the following equation:

$$
\Delta I_{\text {bomb }}=\int_{0}^{Z_{14}} C_{b o m b} d z \times \rho \times N_{A}
$$

where $\rho$ and $\mathrm{N}_{\mathrm{A}}$ are the density of seawater in $\mathrm{kg} \mathrm{m}^{-3}$ and Avogadro number $\left(=6.02 \times 10^{23}\right)$, respectively. The variability $\left(\Delta \mathrm{I}_{\text {bomb }}\right)$ of $\mathrm{I}_{\text {bomb }}$ in each water column during the last $24 \mathrm{yr}$ is expressed as follows:

$$
\Delta I_{\text {bomb }}=I_{1997}-I_{1973}
$$

By substituting equations (2) at 1973 and 1997 for equation (3), we can obtain the following equation:

$$
\Delta I_{\text {bomb }}=\int_{0}^{Z}{ }_{14} C_{1997-1973} d z \times \rho \times N_{A}
$$

where ${ }^{14} \mathrm{C}_{1997-1973}$ is defined as 


$$
{ }^{14} C_{1997-1973}=\left(\Delta^{14} C_{1997} \Delta^{14} C_{1973}\right) \times \alpha \times \Sigma \mathrm{CO}_{2}
$$

The calculated $\Delta \mathrm{I}_{\text {bomb }}$ inventories at Stations $2 \mathrm{~B}, 3$, and 4 are given in Table 2, where we assume the following: (i) surface water is seawater above $25.5 \sigma_{\theta}$ of which the average depth is $200 \mathrm{~m}$; (ii) intermediate water is a water mass of 25.5-27.0 $\sigma_{\theta}$; and (iii) deep water is seawater below $27.0 \sigma_{\theta}$ $(830 \mathrm{~m})$, as defined by Reid (1965), see also Figure 6 . At Stations 1 and $2, \Delta \mathrm{I}_{\text {bomb }}$ cannot be calculated because of the presence of different water masses at the time of the 2 expeditions (this work and GEOSECS). An average value of total of $\Delta \mathrm{I}_{\text {bomb }}$ was $(31.9 \pm 5.0) \times 10^{12}$ atom m$^{-2}$. The annual flux of bomb ${ }^{14} \mathrm{C}$ in the southwestern North Pacific from 1973 to 1997 is $(1.3 \pm 0.3)$ $10^{12}$ atom $\mathrm{m}^{-2} \mathrm{yr}^{-1}$, and is consistent with a previous study in the western North Pacific (Watanabe et al. 1999). The amount of bomb ${ }^{14} \mathrm{C}$ in surface water decreased by $(9.4 \pm 3.0) 10^{12}$ atom m $\mathrm{m}^{-2}$ $\left(0.4 \times 10^{12}\right.$ atom $\left.\mathrm{m}^{-2} \mathrm{yr}^{-1}\right)$; conversely, the amount of bomb ${ }^{14} \mathrm{C}$ in intermediate water increased by $(41.3 \pm 3.4) 10^{12}$ atom $\mathrm{m}^{-2}\left(1.7 \times 10^{12}\right.$ atom $\left.\mathrm{m}^{-2} \mathrm{yr}^{-1}\right)$. On the other hand, in deep water, no variability of $\mathrm{I}_{\text {bomb }}$ over the 24-yr period was found, suggesting that no bomb ${ }^{14} \mathrm{C}$ had been transported into deep water up to the time of sampling in 1997.

Table 2 The variability of the bomb ${ }^{14} \mathrm{C}$ inventory $\left(\Delta \mathrm{I}_{\text {bomb }}\right)$ in the water column, 1973-1997.

\begin{tabular}{|c|c|c|c|c|c|}
\hline \multirow[b]{2}{*}{ Station } & \multirow[b]{2}{*}{ Location } & \multicolumn{4}{|c|}{$\Delta \mathrm{I}_{\text {bomb }}\left(\times 10^{12}\right.$ atom $\left.\mathrm{m}^{-2}\right)$} \\
\hline & & Total & above $25.5 \sigma_{\theta}$ & $25.5-27.0 \sigma_{\theta}$ & below $27.0 \sigma_{\theta}$ \\
\hline $\begin{array}{l}\text { IAEA-2B } \\
\text { G-225 }\end{array}$ & $\begin{array}{r}32.5^{\circ} \mathrm{N} \\
161.9^{\circ} \mathrm{E}\end{array}$ & 37.5 & -7.3 & 44.9 & 0 \\
\hline $\begin{array}{l}\text { IAEA-3 } \\
\text { G-226 }\end{array}$ & $\begin{array}{r}30.6^{\circ} \mathrm{N} \\
170.6^{\circ} \mathrm{E}\end{array}$ & 30.1 & -8.0 & 38.1 & 0 \\
\hline $\begin{array}{l}\text { IAEA-4 } \\
\text { G-227 }\end{array}$ & $\begin{array}{r}25.0^{\circ} \mathrm{N} \\
170.1^{\circ} \mathrm{E}\end{array}$ & 28.2 & -12.8 & 40.9 & 0 \\
\hline Average: & & $31.9 \pm 5.0$ & $-9.4 \pm 3.0$ & $41.3 \pm 3.4$ & 0 \\
\hline \multicolumn{6}{|c|}{ Annual flux: $1.3 \times 10^{12}$ atom $/ \mathrm{m}^{2} \mathrm{yr}$} \\
\hline
\end{tabular}

The increase of bomb ${ }^{14} \mathrm{C}$ in the water column can be considered to be equal to the increase in the intermediate layer. Atmospheric $\Delta^{14} \mathrm{C}$ increased substantially during the $1960 \mathrm{~s}$, and then decreased from the late 1960 s to the present (Levin et al. 1994). The main input of atmospheric bomb ${ }^{14} \mathrm{C}$ was absorbed into surface water over the whole Pacific Ocean between the 1960s and the 1970s. At the same time, excess bomb ${ }^{14} \mathrm{C}$ in surface water was transported northward by advection by the Kuroshio Current and/or Kuroshio Extension Current. Bomb ${ }^{14} \mathrm{C}$ absorbed into surface water in subarctic areas was carried to the intermediate layer by strong vertical mixing. The excess bomb ${ }^{14} \mathrm{C}$ in the intermediate layer in subarctic areas was transported to the subtropical area by North Pacific Intermediate Water (NPIW) (Mahadevan 2001; Aramaki 2002).

\section{CONCLUSIONS}

In the framework of IAEA-MEL's project on Worldwide Marine Radioactivity Studies (WOMARS), water profile samples were taken during the IAEA'97 Pacific Ocean cruise at 10 stations in the southwestern North Pacific Ocean. Some stations were in proximity to the GEOSECS stations sampled in 1973; thus, ${ }^{14} \mathrm{C}$ profiles could be compared over the $24-\mathrm{yr}$ interval. The following conclusions were drawn from the present work: 
- ${ }^{14} \mathrm{C}$ concentrations had decreased in surface waters (by 50-80\%) and increased (by about the same amount) in intermediate waters. In deep waters (below $1000 \mathrm{~m}$ ), the observed ${ }^{14} \mathrm{C}$ concentrations were similar to GEOSECS values (except for Station 7). While a rapid decrease in ${ }^{14} \mathrm{C}$ concentrations was observed from the surface $\left({ }^{14} \mathrm{C}\right.$ approximately $\left.100 \%\right)$ down to $1000 \mathrm{~m}\left({ }^{14} \mathrm{C}\right.$ approximately $-200 \%$ ), the concentrations below $1000 \mathrm{~m}$ were almost constant. The bombproduced ${ }^{14} \mathrm{C}$ inventory had increased by more than $20 \%$ over the 24 -yr period studied.

- The variability of bomb ${ }^{14} \mathrm{C}$ inventories in the water column over the 24 -yr period $\left(\Delta \mathrm{I}_{\text {bomb }}\right)$ was estimated at $(32 \pm 5) 10^{12}$ atom $\mathrm{m}^{-2}$. The amount of bomb ${ }^{14} \mathrm{C}$ in surface water had decreased to (9.4 \pm 3.0$) 10^{12}$ atom $\mathrm{m}^{-2}$; conversely, the amount of bomb ${ }^{14} \mathrm{C}$ in intermediate water had increased to $(41 \pm 4) 10^{12}$ atom $\mathrm{m}^{-2}$. However, no variation of $\mathrm{I}_{\text {bomb }}$ was found in deep water over the period. The average annual flux of bomb ${ }^{14} \mathrm{C}$ has been estimated to be $(1.3 \pm 0.3)$ $10^{12}$ atom $\mathrm{m}^{-2} \mathrm{yr}^{-1}$.

- The results suggest that excess bomb ${ }^{14} \mathrm{C}$ in surface water of the southwestern Pacific Ocean was transported northward by advection by the Kuroshio Current and Kuroshio Extension and then transported into the intermediate layer by North Pacific Intermediate Water (NPIW), which flows southward from the subarctic area to the tropics.

\section{ACKNOWLEDGEMENTS}

The WOMARS project and the IAEA '97 Pacific Ocean Expedition were conducted thanks to the generous support provided by the Science and Technology Agency of Japan (presently the Ministry of Education, Culture, Sports, Science, and Technology). The authors are indebted to their colleagues and the crew of the R/V Bosei Maru for their kind cooperation during the field work. We also wish to thank colleagues at JAERI-MRL and the University of Arizona for sample preparation and ${ }^{14} \mathrm{C}$ AMS measurements. IAEA-MEL operates under a bilateral agreement between the IAEA and the Government of the Principality of Monaco.

\section{REFERENCES}

Aramaki T. 2002. Study on seawater circulation in the western North Pacific and its marginal seas in the viewpoint of distribution of radiocarbon in seawater [PhD dissertation]. Sapporo, Japan: Hokkaido University.

Aramaki T, Mizushima T, Mizutani Y, Yamamoto T, Togawa O, Kabuto S, Kuji T, Gottdang A, Klein M, Mous DJW. 2000. The AMS facility at the Japan Atomic Energy Research Institute (JAERI). Nuclear Instruments and Methods in Physics Research B 172: 18-23.

Aramaki T, Mizushima T, Kuji T, Povinec PP, Togawa O. 2001. Distribution of radiocarbon in the southwestern North Pacific. Radiocarbon 43(2B):857-68.

Broecker WS, Peng T-H, Ostland G, Stuiver M. 1985. The distribution of bomb radiocarbon in the ocean. Journal of Geophysical Research 90:6953-70.

Broecker WS, Sutherland S, Smethie W, Peng T-H. 1995. Oceanic radiocarbon: separation of the natural and bomb components. Global Biogeochemical Cycles 9: 263-88.

Donahue DJ, Linick TW, Jull AJT. 1990a. Isotope-ratio and background corrections for accelerator mass spectrometry radiocarbon measurements. Radiocarbon
32(1):135-42.

Donahue DJ, Jull AJT, Toolin LJ. 1990b. Radiocarbon measurements at the University of Arizona AMS facility. Nuclear Instruments and Methods in Physics Research B 52:224-8.

Gamo T, Horibe Y, Kobayashi H. 1987. Comparison of oceanic $\Delta^{14} \mathrm{C}$ data with those of GEOSECS: vertical profiles in 1973 and 1980 at $30^{\circ} \mathrm{N} 170^{\circ} \mathrm{E}$ in the northwestern Pacific Ocean. Radiocarbon 29(1):53-6.

Kawabe M, Taira K. 1998. Water masses and properties at $165^{\circ} \mathrm{E}$ in the western Pacific. Journal of Geophysical Research 103:12,941-58.

Key RM, Quay PD, Schlosser P, McNichol AP, von Reden KF, Schneider RJ, Elder KL, Stuiver M, Ostlund HG. 2002. WOCE radiocarbon IV: Pacific Ocean results; P10, P13N, P14C, P18, P19 \& S4P. Radiocarbon 44(1):239-392.

Kitagawa H, Masuzawa T, Nakamura T, Matsumoto E. 1993. A batch preparation method of graphite targets with low background for AMS ${ }^{14} \mathrm{C}$ measurements. Radiocarbon 35(2):295-300.

Leboucher V, Orr J, Jean-Baptiste P, Arnold M, Monfray P, Tisnerat-Laborde N, Poisson A, Duplessy J-C. 1999. Oceanic radiocarbon between Antarctica and 
South Africa along WOCE section 16 at $30^{\circ}$ E. Radiocarbon 41(1):51-73.

Levin I, Kromer B, Schoch-Fischer H, Bruns M, Munnich M, Berdau D, Vogel JC, Munnich KO. 1985. 25 years of tropospheric ${ }^{14} \mathrm{C}$ observations in Central Europe. Radiocarbon 27(1):1-19.

Levin I, Kromer B, Schoch-Fischer H, Bruns M, Munnich M, Berdau D, Vogel JC, Munnich KO. 1994. $\Delta^{14} \mathrm{CO}_{2}$ records from sites in Central Europe, Trends '93. In: Boden TA, Kaiser DP, Sepanski RJ, Stoss FW, editors. A Compendium of Data on Global Change. Oak Ridge: ORNL/CDIA-65. p 203-22.

Liong Wee Kwong L, Povinec PP, Jull AJT. 2004. Preparation of graphite targets from small marine samples for AMS radiocarbon measurements. Radiocarbon, these proceedings.

Mahadeva A. 2001. An analysis of bomb radiocarbon trends in the Pacific. Marine Chemistry 73:273-90.

Ostlund HG, Stuiver M. 1980. GEOSECS Pacific radiocarbon. Radiocarbon 22(1):25-53.

Peng T-H, Key RM, Ostlund HG. 1998. Temporal variations of bomb radiocarbon inventory in the Pacific Ocean. Marine Chemistry 60:3-13.

Povinec PP, Togawa O. 1999. Marine radioactivity studies in the world oceans (MARS). Marine Pollution: Proceedings of the International Symposium, Monaco, 5-9 October 1998. International Atomic Energy Agency TECDOC-1094:262-7.

Povinec PP, Livingston HD, Shima S, Aoyama M,
Gastaud J, Goroncy I, Hirose K, Huynh-Ngoc L, Ikeuchi Y, Ito T, La Rosa J, Liong Wee Kwong L, Lee SH, Moriya $\mathrm{H}$, Mulsow S, Oregioni B, Pettersson H, Togawa O. 2003. IAEA'97 expedition to the NW Pacific Ocean-results of oceanographic and radionuclide investigations of the water column. Deep-Sea Research II 50:2607-37.

Reid JL. 1965. Intermediate waters of the Pacific Ocean. Johns Hopkins Oceanographic Studies 2.85 p.

Stuiver M. 1980. Workshop on ${ }^{14} \mathrm{C}$ data reporting. In: Stuiver M, Kra R, editors. Proceedings of the 10th International ${ }^{14} \mathrm{C}$ Conference. Radiocarbon 22(3):9646.

Suga T, Hanawa K, Toba Y. 1989. Thermostad distribution in the North Pacific subtropical gyre: the central mode water and the subtropical mode water. Journal of Physical Oceanography 27:140-52.

Talley LD. 1993. Distribution and formation of North Pacific Intermediate Water. Journal of Physical Oceanography 23:517-37.

Tsunogai S. 1981. A method for chronology of the Pacific and Atlantic deep water and its application. Chikyukagaku 15:70-6. In Japanese with English abstract.

Watanabe YW, Ono T, Harada K, Fukasawa M. 1999. A preliminary study of oceanic bomb radiocarbon inventory in the North Pacific during the last two decades. Journal of Oceanography 55:705-16. 